\title{
Correction to: A Systemic Evaluation of the State of Affairs Following the Negative Outcome of the Referendum in Cyprus Using the Structured Dialogic Design Process
}

\author{
Yiannis Laouris ${ }^{1} \cdot$ Marios Michaelides $^{2} \cdot$ Mustafa Damdelen $^{3} \cdot$ Romina Laouri $^{4}$. \\ Derya Beyatli $^{3}$ - Aleco Christakis ${ }^{5}$
}

Published online: 3 March 2022

(C) The Author(s) 2022

\section{Correction to: Syst Pract Action Res (2009) 22:45-75 \\ https://doi.org/10.1007/s11213-008-9111-y}

The article "A Systemic Evaluation of the State of Affairs Following the Negative outcome of the Referendum in Cyprus Using the Structured Dialogic Design Process", written by Yiannis Laouris, Marios Michaelides, Mustafa Damdelen, Romina Laouri, Derya Beyatli \& Aleco Christakis, was originally published Online First without Open Access. After publication in volume 22, page 45-75 the author decided to opt for Open Choice and to make the article an Open Access publication.

Therefore, the copyright of the article has been changed to (C) The Author(s) 2022 and the article is forthwith distributed under the terms of the Creative Commons Attribution

The original article can be found online at https://oi.org/10.1007/s11213-008-9111-y.

Yiannis Laouris

laouris@cnti.org.cy

Marios Michaelides

mariosmi@spidernet.com.cy

Mustafa Damdelen

damdelen@kibris.net

Romina Laouri

rlaouri@ashoka.org

Derya Beyatli

ibeyatli@kktc.net

Aleco Christakis

CWAaleco@aol.com

Cyprus Neuroscience Technology Institute, Lefkosia, Cyprus

2 Cyprus Intercultural Training Initiative, Nicosia, Cyprus

3 Cyprus EU Association, Nicosia, Cyprus

4 Ashoka Headquarters, Arlington, VA, USA

5 Institute for 21st Century Agoras, Crete, Greece 
4.0 International License, which permits use, sharing, adaptation, distribution and reproduction in any medium or format, as long as you give appropriate credit to the original author(s) and the source, provide a link to the Creative Commons licence, and indicate if changes were made. The images or other third party material in this article are included in the article's Creative Commons licence, unless indicated otherwise in a credit line to the material. If material is not included in the article's Creative Commons licence and your intended use is not permitted by statutory regulation or exceeds the permitted use, you will need to obtain permission directly from the copyright holder. To view a copy of this licence, visit http://creativecommons.org/licenses/by/4.0/.

Open Access This article is licensed under a Creative Commons Attribution 4.0 International License, which permits use, sharing, adaptation, distribution and reproduction in any medium or format, as long as you give appropriate credit to the original author(s) and the source, provide a link to the Creative Commons licence, and indicate if changes were made. The images or other third party material in this article are included in the article's Creative Commons licence, unless indicated otherwise in a credit line to the material. If material is not included in the article's Creative Commons licence and your intended use is not permitted by statutory regulation or exceeds the permitted use, you will need to obtain permission directly from the copyright holder. To view a copy of this licence, visit http://creativecommons.org/licenses/by/4.0/.

Publisher's Note Springer Nature remains neutral with regard to jurisdictional claims in published maps and institutional affiliations. 